\title{
Prenatal air pollution exposure and growth: The role of placental mtDNA content
}

\author{
Diana Clemente ${ }^{1 *}$, Maribel Casas $^{2}$, Carmen Iñiguez ${ }^{3}$, Loreto Santa Marina ${ }^{4}$, Tim S Nawrot ${ }^{5}$, Martine Vrijheid ${ }^{2}$ \\ From Methods in Epidemiology Symposium \\ Leuven, Belgium. 17 September 2015
}

\section{Background and aims}

In recent years, evidence has shown that prenatal trafficrelated air pollution exposure influences fetal growth. Changes in mitochondrial DNA (mtDNA) content may represent a biologically relevant endpoint on the mechanisms underlying the association between air pollution and fetal growth restrictions. In this study, we aimed to assess the role of placental mtDNA content on the association of prenatal $\mathrm{NO}_{2}$ exposure with fetal growth assessed by ultrasound measurements.

\section{Methods}

In this study, we used 333 mother-newborn pairs from the Spanish INMA study (Sabadell: $\mathrm{n}=120$; Gipuzkoa: $\mathrm{n}=$ 152; Valencia: $\mathrm{n}=61$ ). We used temporally adjusted landuse regression models to estimate exposure to nitrogen dioxide $\left(\mathrm{NO}_{2}\right)$. We estimated growth curves for femur length (FL), head circumference (HC), abdominal circumference (AC), biparietal diameter (BPD), and estimated fetal weight (EFW) during pregnancy (weeks 12-20, 12-32 and 20-32). DNA was extracted from placental tissue cells. Relative placental mtDNA content was measured using quantitative real-time polymerase chain reaction.

\section{Results}

Each $10 \mu \mathrm{g} / \mathrm{m}^{3}$ increment in prenatal $\mathrm{NO}_{2}$ exposure was associated with a relative decrease in placental mtDNA content of $4.3 \%$ ( $95 \%$ confidence interval (CI): $-7.4,-1.1 \%$ ). BPD at 12-32 and 20-32 weeks was significantly associated with prenatal $\mathrm{NO}_{2}$ exposure (during weeks 0-12, 0-20, $12-20$ and $0-32$ ). HC at 12-32 and 20-32 weeks was significantly associated with prenatal $\mathrm{NO}_{2}$ exposure during weeks 20-32 and weeks 0-32. The other fetal growth parameters were not significantly associated with prenatal $\mathrm{NO}_{2}$ exposure. Each interquartile range increase in placental

${ }^{1}$ UHasselt, Diepenbeek, Belgium

Full list of author information is available at the end of the article
mtDNA content was significantly associated with an increase of $5.2 \%$ (95\% CI: $0.4,7.8 \%)$ in BPD at weeks 20-32.

\section{Conclusions}

Our results give an implication that prenatal air pollution exposure can impair fetal head growth. Furthermore, we showed that placental mtDNA content can play a role in this adverse effect.

\section{Authors' details}

${ }^{1}$ UHasselt, Diepenbeek, Belgium. ${ }^{2}$ Centre For Research in Environmental Epidemiology (CREAL), Barcelona, Spain. ${ }^{3} \mathrm{FISABIO}$, Valencia, Spain. ${ }^{4} \mathrm{CIBER}$ de Epidemiología y Salud Pública (CIBERESP), Madrid, Spain. ${ }^{5}$ Center for Environmental Sciences (CMK), Hasselt University, Diepenbeek, Belgium.

\section{Published: 17 September 2015}

doi:10.1186/2049-3258-73-S1-P34

Cite this article as: Clemente et al:: Prenatal air pollution exposure and growth: The role of placental mtDNA content. Archives of Public Health 2015 73(Suppl 1):P34.

\section{Submit your next manuscript to BioMed Central and take full advantage of: \\ - Convenient online submission \\ - Thorough peer review \\ - No space constraints or color figure charges \\ - Immediate publication on acceptance \\ - Inclusion in PubMed, CAS, Scopus and Google Scholar \\ - Research which is freely available for redistribution

